\title{
DEMOGRAPHIC CHARACTERISTICS OF TUTORS ON THE INTEGRATION OF INFORMATION AND COMMUNICATION TECHNOLOGY IN TEACHING AND LEARNING IN THE COLLEGES OF EDUCATION
}

\author{
Elizabeth Adoma Sefah', \\ Samuel Obed Amoah', \\ Henry Yaw Acheampong ${ }^{1}$, \\ Francis Britwum ${ }^{2 \mathrm{i}}$ \\ 1St. Monica's College of Education, \\ Department of Education Studies, \\ Ghana \\ ${ }^{2}$ University of Cape Coast, \\ Department of Education and Psychology, \\ Ghana
}

\begin{abstract}
:
The purpose of the study was to examine demographic characteristics of tutors on the integration of information and communication technology in teaching and learning in the Colleges of Education in Ghana. The descriptive survey design was used to conduct the study. The purposive sampling technique was used in the selection process. The sample size was 120 tutors. Independent sample $t$-test and One-way ANOVA were used to analyze the data. The findings showed that there is a significant difference between male and female tutors in their use of ICTs in teaching and learning in the public Colleges of Education in Ghana. The findings revealed that there is no significant difference between tutors with different age and their integration of ICT in teaching and learning. The findings again, indicated that there is no significant difference between the level of academic qualification and the use of ICTs among tutors. The results revealed that there is a significant difference between the use of ICTs among tutors based on their teaching experience. The study recommended that female tutors who could not effectively integrate ICT into the teaching and learning should be identified and supported to integrate ICT into the teaching of the subject. The study recommended that appropriate pedagogical models suitable for the integration of ICTs in teaching and learning should be developed by curriculum designers to assist tutors in their urge to employ them in the teaching and learning process. The study again, recommended that management of the public Colleges of Education in Ghana should seek sponsorship from internet service
\end{abstract}

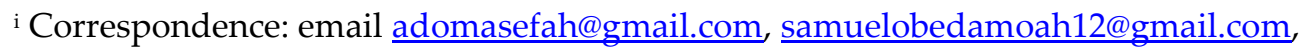
henryacheampongyaw@gmail.com francisbritwum@gmail.com 
providers in Ghana to provide free or affordable and reliable internet connectivity in the colleges to facilitate effective use of ICTs in the teaching and learning in the Colleges of Education.

Keywords: information and communication technology, teaching and learning

\section{Introduction}

Several countries have expressed a strong interest in information communication technology (ICTs), believing that it will improve teaching and learning in educational institutions. Countries all across the world have also been urged to use technology in creative ways to improve learning. Again, major efforts have been made to guarantee that learners are exposed to technologies, in the hope that such integration will enable them (learners) develop the necessary skills to enter the workforce and contribute fully to this technologically driven world. In this context, literature (Watson, 2001; Mutula \& Van Brakel, 2007; United Nations Educational, Scientific and Cultural Organization (UNESCO, 2007) has emphasized that incorporating new technologies into curriculum delivery has both direct and indirect effects on teaching and learning, as well as social and economic development. Watson (2001) also claims that using technology in the classroom benefits students since it allows them to practice technological skills with realworld problems. As a result, the basic assumption is that these technologies are agents of change in teaching and learning approaches, as well as information access.

Despite the fact that ICTs have a substantial impact on every part of human existence, progress in the application of technology in the field of education has been modest (Afari-Kumah \& Tanye, 2009). Vrasidas, Panaou, Antonaki, Aravi, Avraamidou and Theodoridou (2010) went on to say that while technology is available in schools and classrooms in developed countries such as the United States, the situation in underdeveloped countries is concerning. Africa, as a developing country, looks to be lagging behind in terms of employing technology to teach.

Goble and Porter (1977) opined that the highest level of education attained by the teacher may refer to his/her academic or professional qualification. Such academic or professional qualification forms the professionalism of the teacher and its components involve diagnosis, response, evaluation, personal relations, curriculum development, social responsibility and administration. Diagnosis implies the teachers' ability to accurately estimate the educational needs of an individual. Response refers to the teacher to select an appropriate medium of communication that best conveys the Knowledge and skills being presented. Response thus involves performance capabilities of students and their perceptions. Evaluation refers to the ability to assess and measure the growth or nature of the change that has taken place in the student. Personal relations imply the reactions of the nature of the change in the learner. The teacher should be able to motivate, interpret, build realistic self-esteem in the students and develop his self- 
assessment. Curriculum development refers to the planning of teaching-learning activities. It thus includes the breakdown of the subject matter into a sequence of units, with each one being manageable within the allotted period of time (Goble \& Porter, 1977).

For effective performance, the integration of ICTs in teaching and learning in education needs upgrading of teacher's knowledge and appropriate skills. Becker (2000) hence proved that teacher limitations in terms of skills and knowledge in the use of computers hindered integration of computers. Becker (2000) therefore concluded that the integration of computers and other ICTs require teachers who are personally comfortable and at least moderately skilled in using computers themselves; thrives well in schools which allocate time for students to use computers as part of class assignments and where computer activities flow alongside other learning tasks.

Literature shows that an experience in teaching plays an important role for effective integration of ICT in curriculum delivery. In fact, the available literature has established no connection between ICT integration and teachers' years of teaching experience. For example, Chemwei, Njagi and Koech (2014) disclosed that the experience of teachers has a substantial influence on adoption and use of technology in daily classroom activities. Deen-Swarray, Gillwald and Morrell (2012) also indicated that teachers with extensive teaching experience were aged and therefore had a low selfefficacy in access and ease of use of ICT tools in classroom activities. In this context, Chemwei et al. (2014) exemplified that teacher in the age bracket of 41-50 years and above in the teaching profession had challenges using computers.

This is to say that the period of time in which the teacher started or served in teaching, influences the adoption and use of ICT in teaching and learning. That is, the length of service of teachers in the teaching profession has an effect on the use of ICT in daily classroom activities. This is supported by Mulwa and Kimosop (2015) that the teachers who served in the teaching profession for long periods have no interest in ICT. This suggests that teachers with fewer years in teaching profession may tend to be enthusiastic, skilled and interested in the use of ICT tools in the teaching and learning processes. In a related study, Dix (2007) found that earlier-career teachers had more positive view towards ICT use in teaching and learning than recent-career teachers. The presupposition therefore is that the number of years of teaching experience of a teacher has a direct relationship with the use of ICT in teaching. The bottom line is that the more experienced the teachers are, the more they tend to readily use technology in teaching and learning processes.

\section{Statement of the Problem}

Despite efforts to promote ICT integration, it is discovered that the majority of these programs aimed at ensuring ICT integration in Ghanaian education were fragmented, unstructured, and did not cover all of the schools (Nyarko, 2007). Regardless of the procedures put in place in Ghana to ensure ICT integration in education, researchers such 
as Baek, Jong and Kim (2008) discovered that ICT use in teaching and learning in the educational environment was very low, even falling behind the commercial sector.

Integration of ICT in the teaching and learning has also been identified as a challenge in many African countries, notably in African public universities especially in the Colleges of Education (Awidi, 2008). Similarly, there is little information on how ICTs may be spread and used by teachers in Ghanaian schools, confirming the conclusions of Aduwa-Ogiegbaen and Iyamu (2005) study that found large discrepancies in the usage of ICTs between rural and urban schools, favoring urban schools.

In many universities in Ghana, for example, the ICT equipment required to increase good lecture delivery as well as successful learning is a major constraint (Edumadze \& Owusu, 2013). That is to say, most public Colleges of Education in Ghana still lack basic ICT equipment and resources such as computers, speakers, projectors, and dependable internet connectivity. Until recently, certain professors and tutors in Ghana's public universities and colleges of education had little exposure to ICT tools such as computers (Edumadze \& Owusu, 2013). It is therefore pertinent to investigate demographic characteristics of tutors on the integration of ICT in teaching and learning in the Colleges of Education in Ghana.

\section{Hypotheses}

1) $\mathbf{H}_{0}$ : There is no statistically significant difference between tutors with different sex and their integration of ICT in teaching and learning in the Colleges of Education in Ghana.

$\mathbf{H}_{1}$ : There is a statistically significant difference between tutors with different sex and their integration of ICT in teaching and learning in the Colleges of Education in Ghana.

2) $\mathbf{H}_{0}$ : There is no statistically significant difference between tutors with different age and their integration of ICT in teaching and learning in the Colleges of Education in Ghana.

$\mathbf{H}_{1}$ : There is a statistically significant difference between tutors with different age and their integration of ICT in teaching and learning in the Colleges of Education in Ghana.

3) $\mathbf{H}_{0}$ : There is no statistically significant difference between tutors with different academic qualification and their integration of ICT in teaching and learning in the Colleges of Education in Ghana.

$\mathbf{H}_{1}$ : There is a statistically significant difference between tutors with different academic qualification and their integration of ICT in teaching and learning in the Colleges of Education in Ghana.

4) $\mathbf{H}_{0}$ : There is no statistically significant difference between tutors with different years of teaching experience and their integration of ICT in teaching and learning in the Colleges of Education in Ghana. 
$\mathbf{H}_{1}$ : There is a statistically significant difference between tutors with different years of teaching experience and their integration of ICT in teaching and learning in the Colleges of Education in Ghana.

\section{Review of Related Literature}

\subsection{Constructivism Theory}

It is assumed in this theory that the learner uses the knowledge that he or she already have to acquire new knowledge through the facilitator, who is the teacher. According to this notion, knowledge is something that comes from the learner. As a result, Bruner (1990) advised that an individual obtain knowledge through experience. According to him, new knowledge can be derived from existing knowledge without affecting its structure. As a result, this theory proposes that learners derive meaning from new experiences they encounter. Such encounters may arise as a result of the environment in which they find themselves as well as their ongoing interactions with their peers. Bruner (1990) also stated that any circumstance in which creativity arises results in alterations.

Bruner (1990) goes on to say that innovation or creativity is the process of coming up with new information based on a learner's experience. As a result, he claims that learning environmental creativity necessitates learners using their prior knowledge and experience to develop new results relevant to their areas of study. The instructor is only considered as a facilitator in this setting, and his or her major role or task is to direct learners so that they can contribute and construct their own understanding of knowledge, which finally leads to learning.

In addition, the teacher's primary goal should be to guarantee that what he or she teaches ties to or is related to the learners' prior experiences. As a result, teachers that follow the constructivism path should stress what students already know and connect it to what they're learning. According to Jonassen (1997), the learning environment should allow both the instructor and the learner to have clear processes in class activities, and teachers should provide an avenue for students to connect the topic they are studying with the environment. It is hoped that this will enable learners to gain more knowledge, which will help them address problems in their immediate area.

As a result, the constructivism theory emphasizes the need of teachers properly involving learners in the learning and teaching process rather than simply listening to and implementing what their teachers say. This is because, in teaching, the teacher's approach has a significant impact not only on the students' performance in class, but also on their future lives (Bruner, 1990). As a result, it is the teacher's obligation to ensure that students gain knowledge by implementing innovative methodologies such as ICT into their courses in order to increase student performance. This will allow students to speak and interact effectively in class while also preparing them to tackle real-life situations on their own. 


\subsection{Empirical Review}

Harrison, Comber, Fisher, Haw, Lewin, Lunzer, McFarlane, Mavers, Scrimshaw, Somekh, and Watling (2003) conducted one of the most extensive research examining the impact of ICT on academic performance in the United Kingdom. The study looked into the impact of ICTs on performance at key stages 2, 3, and 4 of the general Certificate of Secondary Education (GSCE). Harrison et al. (2003) discovered a substantial link between ICT use and the National Test for English at Key Stage 2. The data at Key Stage 2 also showed that, while there was a favorable correlation between ICT use and performance, it was not statistically significant. The findings at Key Stage 3 revealed a strong positive relationship between ICT use and performance on the National Test for Science, as well as a statistically significant positive relationship between ICT use and Science and Design Technology at Key Stage 4. Based on these findings, it was determined that ICT may be utilized to improve performance in English, Science, and Design Technology at Key Stages 2 and 4 (Harrison et al., 2003).

Students who had access to ICT resources performed well in research constructed tests, standardized tests, and national tests, according to Schacter (1999), who used metaanalysis to investigate the impact of educational technology on Fourth and Eighth Grade students' achievement in West Virginia, United States of America. Makridou-Bousiou (2006) also performed research in Thessaloniki, Greece, on the usefulness of using technology to teach economics in high schools. A total of 65 students were chosen at random for the study. There were 65 pupils in total, 45 in the experimental group and 20 in the control group. Furthermore, whereas the experimental group was educated solely through the production of web pages for research objectives, the control group was not. In the end, both the experimental and control groups were subjected to the same test. The test results revealed that students who were taught using technology scored 14.43 percent on average, whereas those who were taught using traditional techniques scored 13.4. As a result, Makridou-Bousiou (2006) determined that there was no statistically significant difference between pupils who were taught using technology and those who were taught using traditional techniques.

Fried (2006) showed a negative correlation between laptop use in the classroom and learning outcomes among psychology students at Winona State University in the United States of America in a related study. In that study, the participants reported that using a laptop in class disrupted their concentration. The American College Test (ACT), the High School Test (HST), school attendance, and the rate of laptop use in class of participating students were all used as independent variables in the equation to predict academic success using linear regression. With the exception of laptop use, the study found that all of the independent factors were significant and positively connected to academic performance. The regression revealed a beta co-efficient of -0.17 for laptop use, indicating that the more students used computers, the lower their performance. The " $\mathrm{t}$ " and " $\mathrm{p}$ " values for validating the association between laptop use and performance, respectively, were -2.286 and 0.24 . 


\section{Methodology}

\subsection{Research Design}

A research design is a master plan or blueprint that specifies the technique to be followed in order to find an answer to the research questions. Research design describes the conceptual structure in which research is conducted and this constitutes logical sequence, the blue print for data collection, analysis of data and measurement of variables used in the study (Sekaran, 2006). A research design, in its simplest form, refers to the techniques and processes used by a researcher to gather, analyze, and interpret data in order to answer research questions or hypotheses. The descriptive survey design was employed for this this. A descriptive survey research study, according to Kerlinger (2004), is aimed to gather relevant information about the current status of a phenomena. This method is appropriate since it determines the nature of the current state and is a self-report study that necessitates the collection of quantitative data from the sample. It is effective in gathering enormous amounts of data in a short length of time. A descriptive survey is a way for gathering uniform information about a target population's perceptions, attitudes, and other traits in a methodical manner (Seidu, 2007). This entails administering a predetermined set of questions to the research units.

\subsection{Population of the Study}

The study target population consisted of all tutors in the 46 public Colleges of Education in Ghana. The accessible population included 152 tutors in the public Colleges of Education in Ghana, of which one hundred and thirty (130) tutors were chosen to participate in the study. This sample size was based on Gall, Gall and Borg's (2003) recommendation that at least $50 \%$ of the target population is representative in descriptive surveys. The researcher wanted a sample size that was greater than the minimum as suggested by Gall, Gall and Borg's (2003). In this study, the sample size of 130 was deemed adequate for the study because it constituted about $86 \%$ of the accessible population.

\subsection{Sample and Sampling Procedures}

The Colleges of Education in Ghana are in five zones and there are number schools allocated in each of the zones namely Central/Western Zone-7, Eastern/Greater Accra Zone-9, Volta Zone-7, Ashanti/Brong-Ahafo Zone-13, and Northern Zone-10. All the schools in the zones were involved in the study. The purposive sampling technique was used to select 130 tutors for the study. Purposive sampling, according to Creswell (2009), entails selecting participants who are both relevant and have the information needed for the study. In essence, the researcher considered tutors as people who possessed relevant information required to accomplish the purpose of the study. The return rate that was collected from the respondents were 120. Therefore, 120 tutors were used as the sample size. 


\subsection{Data Collection Instrument}

A self-developed structured questionnaire was used for the study. The questionnaire was developed base on literature review. The questionnaire has 5-point Likert scale which ranges from strongly agree $(S A)=5$, Agree $(A)=4$, Neutral $(N)=3$, Disagree $(D)=2$, and Strongly Disagree $(\mathrm{SD})=1$.

\subsection{Pilot Test}

Pre-testing was done to validate the instrument, that is, to find out how valid and reliable the instrument for the main data collection was. The researcher used $10 \%$ of tutors from two public Colleges of Education for pre-testing the instrument. According to Cohen, Manion and Morisson (2004) using 10\% of the sample size for pre-testing an instrument is laudable. The pre-testing was to help update the instrument as well as give clues as to how long the respondents in the main study will require to finish attending to all the items in the questionnaire.

\subsection{Reliability of Instrument}

To determine the reliability of the instrument the questionnaire was subjected to a trial test outside the study area. The instrument was administered to 50 tutors who were not part of the study. The Cronbach's Alpha method of determining reliability co-efficient was used to determine the internal consistency of the instrument. Reliability co-efficient for sections B, C, D, and E were $0.85,0.76,0.86$ and 0.91 respectively. According to Roland and Idsoe (2001), these scores are regarded as significant for a research purpose.

\subsection{Data Analysis}

The researcher initially went over the questionnaire to see which questions had not been answered and which had a lot of missing data. The data was then coded and entered into the SPSS computer software version 20. Independent sample $t$-test and one-way ANOVA were used to test the hypothesis. The results of the analysis were considered to be significant at $\mathrm{p}<.05$.

\section{Findings}

\subsection{Hypothesis 1}

$\mathrm{H}_{0}$ : There is no statistically significant difference between tutors with different sex and their integration of ICT in teaching and learning in the Colleges of Education in Ghana.

To provide answers to this hypothesis, the influence of sex on the use of ICT in the teaching and learning was investigated. The t-test was used to compare the mean difference between sex and the use of ICT in the teaching and learning. The result is presented in Table 1. 
Elizabeth Adoma Sefah, Samuel Obed Amoah, Henry Yaw Acheampong, Francis Britwum DEMOGRAPHIC CHARACTERISTICS OF TUTORS ON THE INTEGRATION OF INFORMATION AND COMMUNICATION TECHNOLOGY IN TEACHING AND LEARNING IN THE COLLEGES OF EDUCATION IN GHANA

Table 1: T-test Results for Sex of Respondents and their Use of ICTs

\begin{tabular}{|l|l|c|c|c|c|c|}
\hline Dependent Variable & Sex & Mean & Std. Dev. & $\mathbf{t}$ & Df & p-value \\
\hline \multirow{2}{*}{ Use of ICT in teaching and learning } & Male & 1.38 & 0.49 & \multirow{2}{*}{31.04} & \multirow{2}{*}{118} & \multirow{2}{*}{0.00} \\
\cline { 2 - 7 } & Female & 1.52 & 0.50 & & & \\
\hline
\end{tabular}

Source: Field Survey (2021)

Results from Table 1 showed that there is significant difference between male $(M=1.38$, $\mathrm{SD}=0.49)$ and female $(\mathrm{M}=1.52, \mathrm{SD}=0.50)$ tutors in their use of ICTs in teaching and learning in the public Colleges of Education in Ghana [ $t(118)=31.04, p<0.05]$. The results implied the sex of the respondents influenced the use of ICT in teaching and learning where the female tutors used ICT in the teaching and learning more than their male counterparts.

\subsection{Hypothesis 2}

$\mathrm{H}_{0}$ : There is no statistically significant difference between tutors with different age and their integration of ICT in teaching and learning in the Colleges of Education in Ghana.

The study examined the difference between age of respondents and their use of ICT in teaching and learning in the public Colleges of Educations in Ghana. ANOVA was used to provide answers to the study. The result is presented in Table 2.

Table 2: ANOVA Results for Age and Use of ICTs

\begin{tabular}{|l|c|c|c|c|c|}
\hline Dependent Variable & Age & Mean & Std. Dev. & F & Sig. \\
\hline \multirow{4}{*}{ Use of ICT in teaching and learning } & Below 31 & 1.18 & 0.33 & & \\
\cline { 2 - 5 } & $31-40$ & 1.21 & 0.64 & \multirow{3}{*}{1.12} & \multirow{3}{*}{0.35} \\
\cline { 2 - 5 } & $41-50$ & 1.19 & 0.45 & 0.14 & \\
\cline { 2 - 5 } & $51-60$ & 1.20 & 0.49 & & \\
\cline { 2 - 5 } & Total & 1.20 & & \\
\cline { 2 - 5 }
\end{tabular}

Source: Field Survey (2021)

The findings from Table 2 revealed that there is no significant deference between tutors in the public Colleges of Education in Ghana with different age and their integration of ICT in teaching and learning. Hence, the null hypothesis that 'There is no statistically significant difference between tutors in the public Colleges of Education in Ghana with different age and their integration of ICT in teaching and learning was accepted while the alternative hypothesis was rejected.

\subsection{Hypothesis 3}

$\mathrm{H}_{0}$ : There is no statistically significant difference between tutors with different academic qualification and their integration of ICT in the teaching and learning in the Colleges of Education in Ghana.

The study examined the influence of academic qualification on the use of ICTs among tutors. The analysis of variance (ANOVA) was employed for the analysis. Table 3 below presents the result of the analysis. 
Elizabeth Adoma Sefah, Samuel Obed Amoah, Henry Yaw Acheampong, Francis Britwum DEMOGRAPHIC CHARACTERISTICS OF TUTORS ON THE INTEGRATION OF INFORMATION AND COMMUNICATION TECHNOLOGY IN TEACHING AND LEARNING IN THE COLLEGES OF EDUCATION IN GHANA

Table 3: ANOVA Results for Academic Qualification and Use of ICTs

\begin{tabular}{|l|l|c|c|c|c|}
\hline Dependent Variable & Academic Qualification & Mean & Std. Dev. & F & Sig. \\
\hline \multirow{4}{*}{ Use of ICT in teaching and learning } & First Degree & 1.15 & 0.82 & & \\
\cline { 2 - 5 } & MED & 1.20 & 0.28 & \multirow{4}{*}{0.56} & \multirow{3}{*}{0.46} \\
\cline { 2 - 5 } & MPHIL & 1.30 & 0.48 & & \\
\cline { 2 - 5 } & Total & 1.20 & 0.64 & & \\
\hline
\end{tabular}

Source: Field Survey (2021)

The findings from Table 3 indicates that there is no significant differences between the level of academic qualification and the use of ICTs among the respondents $[\mathrm{F}(2,117)=$ 0.56, $\mathrm{p}>0.05]$. This implies that the use of ICTs in teaching does not depend on the level of academic qualification among tutors. Therefore, the null hypothesis that 'There is no statistically significant difference between tutors in the public Colleges of Education in Ghana with different academic qualification and their integration of ICT in teaching and learning was accepted while the alternative hypothesis was rejected.

\subsection{Hypothesis 4}

$\mathrm{H}_{0}$ : There is no statistically significant difference between tutors with different years of teaching experience and their integration of ICT in teaching and learning in the Colleges of Education in Ghana.

The study examine tutors in the College of Education with different years of teaching experience. ANOVA was used in testing data. The result is presented in Table 4 .

Table 4: ANOVA for Teaching Experience and Use of ICT

\begin{tabular}{|l|l|c|c|c|c|}
\hline Dependent Variable & Experience & Mean & Std. Dev. & F & Sig. \\
\hline \multirow{4}{*}{$\begin{array}{l}\text { Use of ICT in teaching and } \\
\text { learning of Social Studies }\end{array}$} & $1-5$ & 1.35 & 0.71 & & \\
\cline { 2 - 5 } & $6-10$ & 1.19 & 0.49 & & \\
\cline { 2 - 5 } & $11-15$ & 1.20 & 0.55 & \multirow{4}{*}{2.85} & 0.00 \\
\cline { 2 - 5 } & $16-20$ & 1.21 & 0.31 & & \\
\cline { 2 - 5 } & Above 20 & 1.20 & 0.36 & & \\
\cline { 2 - 4 } & Total & 1.23 & 0.42 & & \\
\hline
\end{tabular}

Source: Field Survey (2021).

The results in Table 4 revealed that there is a significant difference between the use of ICTs among tutors $[F(4,115)=2.85, p<0.05]$ based on their teaching experience. The results showed that teaching experience influenced the use of ICT among the tutors in the public Colleges of Education. Therefore, the null hypothesis that 'There is no statistically significant difference between tutors in the public Colleges of Education in Ghana with different teaching experience and their integration of ICT in teaching and learning was rejected while the alternative hypothesis was accepted. 


\section{Discussions}

The study showed that there is a significant difference between male $(\mathrm{M}=1.38, \mathrm{SD}=0.49)$ and female $(\mathrm{M}=1.52, \mathrm{SD}=0.50)$ tutors in their use of ICTs in teaching and learning in the public Colleges of Education in Ghana [t $(118)=31.04, \mathrm{p}<0.05]$. This conclusion backed up prior research that found significant variations in ICT integration between male and female tutors. Males, for example, exhibited a somewhat more positive attitude about ICT use than females, according to Omollo, Indoshi, and Ayere (2013). Male teachers exhibited a more favorable attitude toward computer use than female teachers, according to Gode, Obegi, and Macharia (2014). Female tutors have been found to have a negative impression of the use of ICTs and are uncomfortable using them in teaching activities, which obstructs the use of ICTs in the educational curriculum (Birgit, 2011). Male tutors, on the other hand, appear to be more at ease and are more likely to use ICT gadgets in their teaching and learning processes.

The findings revealed that there is no significant deference in terms of the use of ICTs in teaching and learning in the public Colleges of Education $[F(3,116)=1.12, p>0.05]$ due to age. These findings contrast prior research, which revealed that age is a crucial factor determining the usage of ICTs in teaching and learning among Ghanaian tutors (Osei et al., 2014). Similarly, despite the findings of this study, Chemwei et al. (2014) indicated that teachers in the age group of 41-50 years and above in the teaching profession had difficulties using computers.

The findings again, indicated that there is no significant differences between the level of academic qualification and the use of ICTs among the respondents $[F(2,117)=$ $0.56, \mathrm{p}>0.05]$. This finding refutes prior claims that academic qualifications had an impact on the usage of ICT in teaching and learning. According to Becker (2000), the higher the level of academic qualification, the more tutors use ICT in teaching and learning, and Roblyer, Edwards, and Havriluk (2004) added that tutors need more skills training and academic qualification improvement to improve the integration of ICT into teaching and learning processes.

The results revealed that there is a significant difference between the use of ICTs among tutors $[\mathrm{F}(4,115)=2.85, \mathrm{p}<0.05]$ based on their teaching experience. The findings back with a study by Chemwei, Njagi, and Koech (2014), which revealed that instructors' experience has a significant impact on the acceptance and usage of technology in regular classroom activities. Deen-Swarray, Gillwald, and Morrell (2012) backed up prior findings, stating that teachers with a lot of experience were older and hence had low selfefficacy in terms of accessing and using ICT resources in classroom activities. This means that the length of time a teacher has been teaching or has served as a teacher has an impact on the adoption and usage of ICT in Social Studies teaching and learning. Mulwa and Kimosop (2015) found that teachers who have been in the teaching profession for a long time show little interest in ICT, which has a significant impact on how ICT is integrated into teaching and learning activities. 


\section{Conclusion and Recommendations}

It's worth noting that respondents' sex, age, academic qualifications and experience all had a role in the incorporation of ICTs into teaching and learning activities in the public Colleges of Education in Ghana. This suggests that sex, age, academic qualification and teaching experience of tutors need to be considered in decisions regarding the integration of ICT into the teaching and learning in the public Colleges of Education in Ghana. The study recommends that female tutors who could not effectively integrate ICT into the teaching and learning should be identified and supported to integrate ICT into the teaching of the subject. The study recommends that appropriate pedagogical models suitable for the integration of ICTs in the teaching and learning process should be developed by curriculum designers to assist tutors in their urge to employ them in the teaching and learning process. The study again, recommends that management of the public Colleges of Education in Ghana should seek sponsorship from internet service providers in Ghana to provide free or affordable and reliable internet connectivity in the colleges to facilitate effective use of ICTs in the teaching and learning in the Colleges of Education in Ghana.

\section{Conflict of Interest Statement}

The authors declare no conflicts of interests.

\section{About the Authors}

Elizabeth Adoma Sefah is an academic at St. Monica's College of Education. He currently serves as a tutor at the Department of Education Studies at St. Monica's College of Education. He holds Master of Philosophy in Basic Education. Her areas of interest are technology enhanced education, learning assessment and curriculum development.

Samuel Obed Amoah is a tutor and as well the Head of Department at St. Monica's College of Education in the Department of Education studies. He holds Master of Philosophy in Educational Psychology. His research interests include Educational Psychology and Social Psychology.

Henry Yaw Acheampong is a tutor at St. Monica's College of Education in the Department of Education studies. He holds Master of Philosophy in Educational Psychology. His research interests include Educational Psychology and Social Psychology and Adolescent Psychology.

Francis Britwum is a PhD student at the University of Cape Coast in the Department of Education and Psychology. His research interests include Educational Psychology and Teaching and Learning. 


\section{References}

Aduwa-Ogiegbaen, S. E., \& Iyamu, E. O. S. (2005). Using information and communication technology in secondary schools in Nigeria. Journal of Educational Technology $\mathcal{E}$ Society, 8(1), 104-112.

Afari-Kumah, E., \& Tanye, H. A. (2009). Tertiary students' view on information and communications technology usage in Ghana. Journal of Information Technology Impact, 9(2), 81-90.

Awidi, I. T. (2008). Developing an e-learning strategy for public universities in Ghana. Retrieved July 7, 2014 from http://www.educause.edu/ero/article/developingelearning-strategy-public-universities-ghana

Baek, Y. G., Jong, J., \& Kim, B. (2008). What makes teachers use of technology in the classroom? Exploring the factors affecting facilitation of technology. Computers and Education, 50(8), 224-234.

Becker, H. J. (2000). Findings from the teaching, learning and computing survey: Is Larry Cuban right? Education Policy Analysis Archives, 8(51). Retrieved 12/07/07 http://epaa.asu.edu/epaa/v8n51/

Birgit, E. (2011). Supportive and hindering factors to a sustainable implementation of ict in schools. Journal for Educational Research Online, 3(1), 75-103.

Bruner, J. (1990). Acts of meaning. Cambridge, MA: Harvard University press.

Chemwei, B., Njagi, K., \& Koech, S. J. (2014). Assessment of information and communication technology (ICT) integration in instruction in teacher education. Journal of Educational and Instructional Studies in the World, 2(3), 2146-7463

Cohen, L., Manion, L. \& Morrison, K. R. B. (2004). A guide to teaching practice (fifth edition). London: Routledge.

Creswell, J. W. (2009). Research design, qualitative, quantitative and mixed method approaches (3rd Ed.). Sage Publications Inc.

Deen-Swarray, M., Gillwald, A., \& Morrell, A. (2012). Lifting the veil on ICT gender indicators in Africa. Research ICT Africa \& University of Cape Town. Evidence for ICT Policy Action.

Dix, K. L. (2007). A longitudinal study examining the impact of ICT adoption on students and teachers. PH.D. Thesis Report, Flinders University of South Australia.

Fried, C. B. (2006). In- class laptop use and its effects on student learning. Computers and Education, 50, 906-914.

Gall, M. D., Gall, J. P., \& Borg, W. R. (2003). Educational research: An introduction (8th edition). Needham Heights MA: Allyn \& Bacon

Goble, N. M., \& Porter, J. F. (1977). The changing role of the teacher. UNESCO.

Gode, V. O., Obegi, F. M., \& Macharia, P. (2014). Factors influencing integration of information and communication technologies in public primary teacher training colleges in central Region of Kenya. Journal of Emerging Trends in Computing and Information Sciences, 5(12), 2079-8407. 
Harrison, C., Comber, C., Fisher, T., Haw, K., Lewin, C., Lunzer, E., McFarlane, A., Mavers, D., Scrimshaw, P., Somekh, B., \& Watling, R. (2003). The impact of Information and Communication Technologies on pupil learning and attainment. Retrieved on 23/03/2013 from http://www.beeit.co.uk/Guidance\%20Docs/Becta\%20Files/Reports\%20and\%20pu blications/105a\%20ImpaCT2.pdf.

Jonassen, D. (1997). Designing constructivist learning environments. SpringVerlog. Kerlinger, F. N. (2004). Foundation of behavoural research. Second Edition. Surjeet.

Makridou-Bousiou, D. (2006). The effectiveness of technology in teaching high school economics. Journal of Information Technology Impact, 6(1), 9-18.

Mulwa, D. M., \& Kimosop, M. K. (2015). The relationship between head teachers' level of integration of computers in the management of curriculum in secondary schools and their personal characteristics. Los Angeles: SAGE Publications Ltd.

Mutula, S. M., \& Van Brakel, P. (2007). ICT skills readiness for the emerging global digital economy among small businesses in developing countries: Case study of Botswana. Library Hi Tech, 25(2), 231-245.

Nyarko, E. (2007). Developing ICT enabled education -the future for Ghana: Connect on line $\begin{array}{llll}\text { Retrieved } & \text { M } & \text { March }\end{array}$ http://www.iconnectonline.org/Documents/Ghana\%20Elearning\%202007\%20eng -\%20iConnect.pdfNorris

Omollo, D. O., Indoshi, F. C., \& Ayere, M. A. (2013). Attitude of teachers and students towards use of information and communication technology in the implementation of biology curriculum in selected secondary schools. Research Journal in Organizational Psychology \& Educational Studies, 2(3), 76-83.

Osei, C. D., Larbi, E., \& Osei-Boadu, Y. (2014). Multidimensional barriers to information and communication technology adoption among senior high school teachers in Ghana. International Journal of Education and Research, 2(12), 389-396.

Roblyer, M. D., Edwards, J., \& Havriluk, M. A. (2004). Integrating educational technology into teaching (4th Ed.), Upper Saddle River, NJ: Prentice Hall.

Roland, E., \& Isdoe, T. (2001). Aggression and bullying. Aggressive Behavior, 27, 446-462.

Schacter, J. (1999). The impact of educational technology on student achievement: What the most current research has to say. California: The Milken Family Foundation.

Seidu, A. (2007). Modern approaches to research in educational administration. Kumasi: Payless Publication Limited.

Sekaran, U. (2006). Research methods for business: A skill-building approach (3 ${ }^{\text {rd }}$ ed.). New York: John Wiley.

UNESCO (2007). ICT competency standards for teachers- implementation guidelines version 1.0. Retrieved from http://www.unesco.org/en/competency-standards-teachers.

United Nations Educational, Scientific, and Cultural Organization (UNESCO) (2008). ICT competence standards for teachers. Paris: UNESCO. 
Vrasidas, C., Pattis, I., Panaou, P., Antonaki, M., Aravi, C., Avraamidou, L., \& Theodoridou, K. (2010). Teacher use of ICT: Challenges and opportunities. Proceedings of the 7th International Conference on Networked Learning. Available at http://www.lancaster.ac.uk/fss/organisations/netlc/past/nlc2010/abstracts/PDFs/ Vrasidas.pdf. Retrieved on March 15, 2014.

Watson, D. M. (2001). Pedagogy before technology: Re-thinking the relationship between ICT and teaching. Education and Information Technologies, 6(4), 251-266. 
Elizabeth Adoma Sefah, Samuel Obed Amoah, Henry Yaw Acheampong, Francis Britwum

DEMOGRAPHIC CHARACTERISTICS OF TUTORS ON THE INTEGRATION OF

INFORMATION AND COMMUNICATION TECHNOLOGY IN TEACHING

AND LEARNING IN THE COLLEGES OF EDUCATION IN GHANA

Creative Commons licensing terms

Authors will retain the copyright of their published articles agreeing that a Creative Commons Attribution 4.0 International License (CC BY 4.0) terms will be applied to their work. Under the terms of this license, no permission is required from the author(s) or publisher for members of the community to copy, distribute, transmit or adapt the article content, providing a proper, prominent and unambiguous attribution to the authors in a manner that makes clear that the materials are being reused under permission of a Creative Commons License. Views, opinions and conclusions expressed in this research article are views, opinions and conclusions of the author(s). Open Access Publishing Group and European Journal of Open Education and E-learning Studies shall not be responsible or answerable for any loss, damage or liability caused in relation to/arising out of conflict of interests, copyright violations and inappropriate or inaccurate use of any kind content related or integrated on the research work. All the published works are meeting the Open Access Publishing requirements and can be freely accessed, shared, modified, distributed and used in educational, commercial and non-commercial purposes under a Creative Commons Attribution 4.0 International License (CC BY 4.0). 